\title{
Pertumbuhan Rumput Gajah Kerdil (Pennisetum purpureum 'Mott') di Lahan Terbuka Bekas Penambangan Batu Kapur Kawasan Karst Gombong Jawa Tengah
}

\author{
Doso Sarwanto $^{1}$ dan Sari Eko Tuswati ${ }^{1}$ \\ Fakultas Peternakan Universitas Wijayakusuma Purwokerto \\ Email :dososarwanto@gmail.com
}

\begin{abstract}
The negative impact of limestone mining on a karst area around Gombong is the destruction of ecosystem. Ecosystem's destruction will decrease the variety, productivity, quality and continuity of indigenous livestock forages. The aim of this research is to know the growth rate of Dwarf Elephant grass (Pennisetum purpureum 'Mott') in the post mining limestone with various methods of planting. The method used in this research is an experimental method in an open field that was used for limestone mining by using Completed Random Design. The treatment consists of 4 kinds of planting methods with 4 repetitions, while the research treatment used in this experiment is the RG (the field with Dwarf Elephant Grass); RGL (the field with Dwarf Elephant Grass + peanut legume); RGK (the field with Dwarf Elephant Grass + goat's compost $1,5 \mathrm{~kg} / \mathrm{m}^{2}$ ) and RGKL (the field with Dwarf Elephant Grass + peanut legume + goat's compost $1,5 \mathrm{~kg} / \mathrm{m}^{2}$ ). The parameter used for the research is the growth rate which includes the plant's height, the length of the leaves, and also the width of Dwarf Elephant Grass's leaves (Pennisetum purpureum 'Mott') until the $8^{\text {th }}$ week. The result of this research shows that the use of goat's compost $1,5 \mathrm{~kg} / \mathrm{m}^{2}$ and planting of peanut can give significant results to the growth of Dwarf Elephant Grass in open field that was used for limestone mining.
\end{abstract}

Key word : Dwarf Elephant Grass, Pennisetum purpureum 'Mott', Peanut, Karst Gombong

\section{Abstrak}

Dampak negatif dari penambangan batu kapur di kawasan karst Gombong adalah terjadinya kerusakan ekosistem. Kerusakan ekosistem dapat mengakibatkan menurunnya keragaman serta turunnya produktivitas, kualitas dan kontinyuitas hijauan pakan indigenous. Penelitian bertujuan untuk mengetahui tingkat pertumbuhan rumput Gajah Kerdil (Pennisetum purpureum 'Mott' ) di lahan bekas penambangan batu kapur dengan berbagai metode penanaman. Metode penelitian yang digunakan adalah metode eksperimental di lahan terbuka bekas penambangan batu kapur dengan mengggunakan Rancangan Acak Lengkap (RAL). Perlakuan terdiri dari 4 macam metode penanaman dengan ulangan sebanyak 4 kali, sedangkan macam perlakuan penelitian adalah : RG (Lahan ditanami rumput Gajah Kerdil); RGL (Lahan ditanami rumput Gajah Kerdil + kacang tanah); RGK (Lahan ditanami rumput Gajah Kerdil + kompos kambing 1,5 kg/m ${ }^{2}$ ) dan RGKL (Lahan ditanami rumput Gajah Kerdil + kompos kambing 1,5 $\mathrm{kg} / \mathrm{m}^{2}+$ kacang tanah). Parameter yang diukur adalah tingkat pertumbuhan yang meliputi tinggi tanaman, panjang daun dan lebar daun rumput Gajah Kerdil dari umur 1 minggu sampai umur 8 minggu. Hasil penelitian menunjukkan bahwa pemberian kompos kambing sebanyak $1,5 \mathrm{~kg} / \mathrm{m}^{2}$ dan penanaman kacang tanah dapat memberikan hasil yang nyata terhadap pertumbuhan rumput Gajah Kerdil (Pennisetum purpureum 'Mott') di lahan bekas penambangan batu kapur.

Kata Kunci : Rumput Gajah Kerdil, Pennisetum purpureum 'Mott', Kacang tanah, Karst Gombong

\section{Pendahuluan}

Kebijakan pemerintah Indonesia pada saat ini adalah pengembangan infrastruktur di berbagai wilayah. Sejalan dengan itu kebutuhan bahan bangunan seperti batu kapur akan semakin meningkat. Kegiatan penambangan batu kapur di kawasan karst Gombong yang telah berlangsung sejak tahun 1963 sampai saat ini terus berjalan. Padahal kawasan karst menurut Surat Keputusan Menteri Energi dan Sumber Daya Mineral Nomor : $1456 \mathrm{~K} / 20 / \mathrm{MEM} / 2000$ adalah kawasan yang mempunyai beberapa nilai strategis, berupa : a). Nilai ekonomi b). Nilai ilmiah dan c). Nilai kemanusian. Oleh karena itu sejak tahun 2003 pegunungan kapur Gombong ditetapkan sebagai kawasan karst berdasarkan Surat Keputusan Menteri Energi dan Sumber Daya Mineral Nomor : 961.K/40/MEM/2003 dan Surat Keputusan
Menteri Energi dan Sumber Daya Mineral Nomor : 3043.K/40/MEM/2014.

Dampak negatif dari penambangan batu kapur di kawasan karst Gombong yang telah berlangsung lama tersebut adalah terjadinya kerusakan ekosistem. Kerusakan ekosistem dapat mengakibatkan menurunnya keragaman serta turunnya produktivitas, kualitas dan kontinyuitas hijauan pakan indigenous. Hasil penelitian Sarwanto, Tuswati dan Widodo (2015) di kawasan karst Gombong menunjukkan bahwa wilayah tertutup atau wilayah yang belum mengalami penambangan batu kapur terdapat sekitar 20 spesies hijauan pakan indigenous yang meliputi 7 rumput $(35,0 \%)$, 4 legum $(20,0 \%), 7$ perdu $(35,0 \%)$ dan 2 spesies paku-pakuan $(10,0 \%)$ dengan produksi segar hijauan pakan indigenous yang mencapai 29,75 ton/ha/tahun. Kondisi ini jauh 
berbeda dari hasil penelitian Sarwanto dan Prayitno (2015) di wilayah terbuka bekas penambangan batu kapur karst Gombong hanya menemukan 13 spesies hijauan pakan indigenous. yang terdiri dari 7 rumput $(53,8 \%), 2$ legum $(15,4 \%)$ dan 4 perdu $(30,8 \%)$ dengan produksi segar hijauan pakan indigenous hanya sebesar 8,4 ton/ha/tahun. Kerusakan ekosistem karst akibat penambangan batu kapur juga telah dinyatakan oleh Utama et al. (2016) dan Purnaweni (2014) bahwa kawasan karst memiliki peran penting dalam ekosistem, seperti menyediakan air bersih, material alam berbasis kapur, dan pengendali perubahan iklim. Meskipun sangat berperan dalam ekosistem, kawasan karst rentan terhadap gangguan dinamika sosial ekonomi masyarakat yang tidak terarah seperti penambangan batu kapur. Penambangan batu kapur akan mengubah bentang alam secara signifikan dan sangat berpotensi merusak lingkungan yang kerugiannya bahkan dapat mengalahkan kemanfaatan yang dapat dipetik dari kegiatan penambangan. Kerusakan kawasan karst terjadi pula di Provinsi Guizhao China, untuk mengatasinya dibutuhkan kompensasi ekologis selama 20 tahun dan biaya yang sangat besar. Permasalahan kompensasi ekologis dapat dikurangi apabila masyarakat kawasan karst melakukan penanaman tanaman pangan, pemeliharaan lebah, kerajinan tangan dan ekowisata (Zhou, 2014).

Kerusakan ekosistem akibat penambangan batu kapur di Indonesia dapat dikurangi dengan melakukan revegetasi melalui introduksi hijauan pakan yang dapat digunakan sebagai pakan ternak kambing. Rumput Gajah Kerdil (Pennisetum purpureum 'Mott') memiliki banyak keunggulan karena mengandung protein $10-15 \%$, produktivitas tinggi, dan serat kasarnya yang rendah (Urribarri, Ferrer dan Colina, 2005), tekstur daun dan batang yang halus dan lunak serta persentase daun yang tinggi $76 \%$ (Tudsri et al. 2002), kandungan protein kasar sekitar 13,3 13,9\% (Wijitphan, Lorwilai dan Arkaseang, 2009), namun tetap membutuhkan perawatan yang intensif. Menurut Kozloski, Perottoni dan Sanchez (2005) produktivitas dan kualitas rumput Gajah Kerdil lebih dipengaruhi oleh umur pemotongan dan kondisi iklim pada waktu penanaman sampai pada waktu panen. Produktivitas berupa pertumbuhan rumput Gajah Kerdil dapat dilakukan dengan penanaman campuran dengan kacang tanah (Arachis hypogaea L.) dan pemberian kompos kambing. Penanaman kacang tanah diharapkan dapat meningkatkan kandungan nitrogen dalam tanah bekas penambangan batu kapur dan limbahnya dapat digunakan sebagai pakan kambing. Rusdy (2012) menyatakan bahwa pertana man campuran rumput dengan legum dapat mengurangi biaya pemupukan karena N yang difiksasi oleh bakteri Rhizobium yang bersimbiosis pada legum dapat digunakan oleh legum dan rumput untuk memenuhi kebutuhan nitrogennya. Pemberian kompos kambing diharapkan dapat meningkatkan pertumbuhan rumput Gajah Kerdil di lahan terbuka bekas penambangan batu kapur.

Penelitian bertujuan untuk mengetahui tingkat pertumbuhan (tinggi tanaman, panjang daun dan lebar daun) rumput Gajah Kerdil di lahan bekas penambangan batu kapur kawasan karst Gombong Jawa Tengah dengan berbagai meode penanaman. Menurut Zhang (2010) ciri morfologi seperti tinggi tanaman, panjang daun, lebar daun mempunyai korelasi positif terhadap tingkat produksi tanaman rumput Gajah.

\section{Metode Penelitian}

Materi yang digunakan dalam penelitian ini adalah rumput Gajah Kerdil dan kacang tanah. Lokasi penelitian bertempat di lahan terbuka bekas penambangan batu kapur yang terlantar selama lebih dari 10 tahun, terletak di Desa Kalisari Kecamatan Rowokele Kabupaten Kebumen (Gambar 1). Metode penelitian yang digunakan adalah metode eksperimental di lahan terbuka bekas penambangan batu kapur dengan mengggunakan Rancangan Acak Lengkap (RAL). Perlakuan terdiri dari 4 macam metode penanaman dengan ulangan sebanyak 4 kali, sedangkan macam perlakuan penelitian adalah sebagai berikut : Kerdil

RGL : Penanaman campuran rumput Gajah Kerdil + kacang tanah

RGK : Penanaman tunggal rumput Gajah Kerdil + kompos kambing $1,5 \mathrm{~kg} / \mathrm{m}^{2}$

RGKL : Penanaman campuran rumput Gajah Kerdil + kacang tanah + kompos kambing $1,5 \mathrm{~kg} / \mathrm{m}^{2}$

Peubah respon yang diukur adalah pertumbuhan rumput Gajah Kerdil yang meliputi tinggi tanaman, panjang daun dan lebar daun yang diukur mulai umur 1 - 8 minggu. Data pertumbuhan rumput Gajah Kerdil dari umur $1-8$ minggu disajikan secara deskriptif, sedangkan data akhir pertumbuhan rumput Gajah umur 8 minggu dianalisis dengan analisis ragam dan apabila terdapat perbedaan nyata dilanjutkan dengan uji lanjut menggunakan uji Beda Nyata terkecil (BNT) sesuai petunjuk Steel dan Torrie (1993). 


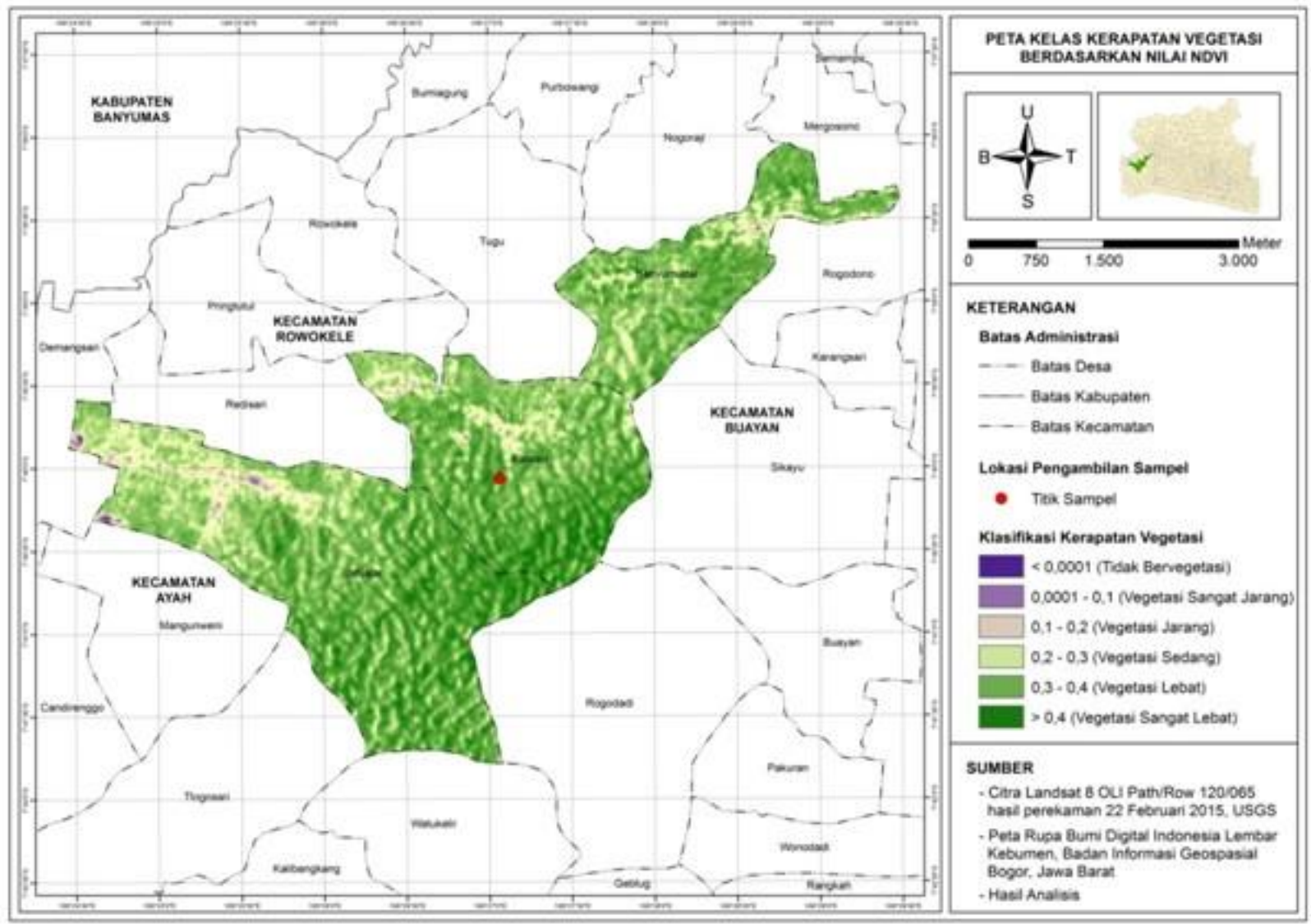

Gambar 1. Lokasi Penelitian penanaman rumput Gajah Kerdil di lahan bekas penambangan batu kapur kawasan karst Gombong

\section{Hasil dan Pembahasan}

\section{Tinggi Tanaman}

Pertumbuhan tinggi tanaman rumput Gajah Kerdil umur $1-8$ minggu mempunyai tingkat pertumbuhan yang bervariasi. Tinggi tanaman pada umur 1 minggu sekitar $12-16 \mathrm{~cm}$, sedangkan pada akhir pengukuran umur 8 minggu sebesar $75-88 \mathrm{~cm}$. Pertumbuhan tinggi tanaman rumput Gajah Kerdil umur $1-8$ minggu dapat dilihat pada Gambar 2. Pada Gambar 2 terlihat bahwa pada akhir pengukuran RGKL mempunyai tinggi tanaman yang tertinggi yaitu 88 $\mathrm{cm}$ dibandingkan $\mathrm{RG}: 75 \mathrm{~cm}, \mathrm{RGL}: 77 \mathrm{~cm}$ dan RGK : $86 \mathrm{~cm}$.

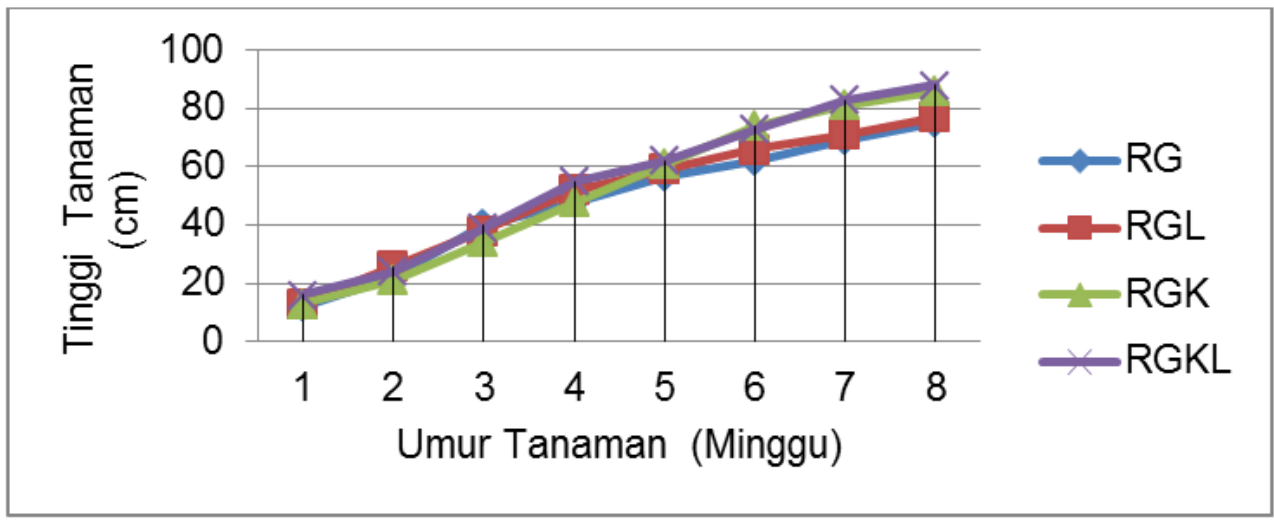

Gambar 2. Pertumbuhan tinggi tanaman rumput Gajah Kerdil di lahan bekas penambangan batu kapur kawasan karst Gombong. 
Hasil analisis ragam menunjukkan bahwa metode penanaman berpengaruh nyata $(P<0,05)$ terhadap tinggi tanaman rumput Gajah Kerdil. Hasil uji lanjut memperlihatkan bahwa RG dan RGL mempunyai tinggi tanaman yang sama namun berbeda dengan RGK dan RGKL, sedangkan RGK dan RGKL mempunyai tinggi tanaman yang sama. Hasil uji lanjut tinggi tanaman rumput Gajah Kerdil di lahan bekas penambangan batu kapur dengan beberapa metode penanaman dapat dilihat pada Gambar 3. Hasil uji lanjut memperlihatkan bahwa penambahan kompos kambing $1,5 \mathrm{~kg} / \mathrm{m}^{2}$ memberikan pengaruh yang lebih nyata untuk meningkatkan tinggi tanaman rumput Gajah Kerdil dilahan bekas penambangan batu kapur. Menurut Nurshanti (2009) kompos kambing mempunyai pengaruh yang lebih baik dibandingkan kompos sapi dan ayam karena dapat menggemburkan lapisan permukaan tanah, meningkatkan populasi jasad renik, mempertinggi daya serap dan daya simpan air sehingga dapat meningkatkan produktivitas tanaman.

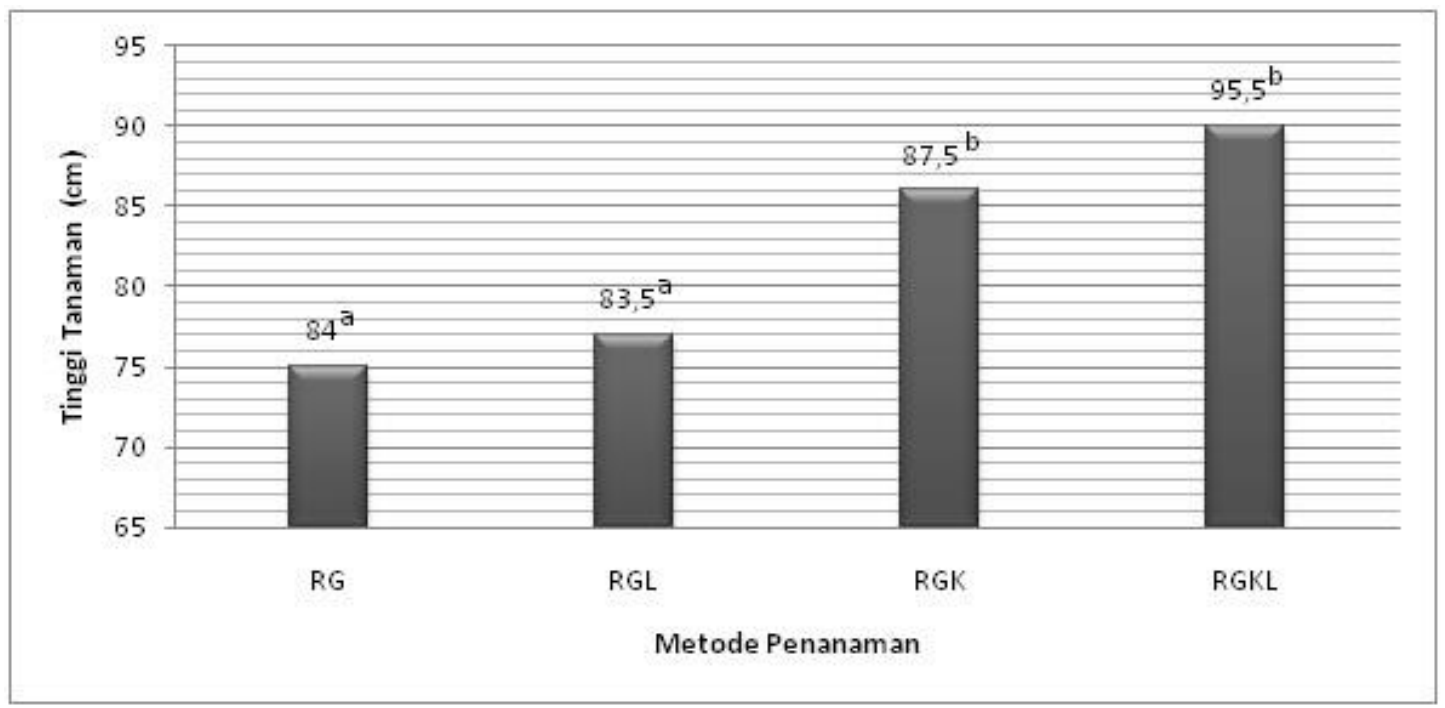

Gambar 3. Rataan tinggi tanaman rumput Gajah Kerdil di lahan bekas penambangan batu kapur pada berbagai metode penanaman.

Keterangan : ${ }^{a, b}$ huruf yang berbeda pada diagram menunjukkan perbedaan yang nyata $(P<0,05)$.

Meskipun demikian lahan terbuka bekas penambangan batu kapur yang digunakan adalah lahan yang telah berumur lebih dari 10 tahun, sehingga lahan tersebut telah mempunyai sedikit unsur hara. Sarwanto dan Prayitno (2015) menyatakan bahwa tanah terlantar bekas penambangan batu kapur mempunyai unsur hara yang rendah yaitu $\mathrm{N}$ total $0,049-0,141 \%, \mathrm{P}_{2} \mathrm{O}_{5}$ total $0,067-0,133 \%$ dan $\mathrm{K}_{2} \mathrm{O}$ total $0,086-$ $0,100 \%$ namun masih dapat ditumbuhi rumput liar seperti Cynodon dactylon, Imperata cylindrica, Ageratum conyzoides dan Mikania micrantha.

\section{Panjang Daun}

Hasil pengukuran panjang daun rumput Gajah Kerdil di lahan terbuka bekas penambangan batu kapur pada berbagai metode penanaman pada umur 1 minggu relatif sama yaitu $R G$ : $2 \mathrm{~cm}, \mathrm{RGL}: 2 \mathrm{~cm}$, RGK : $3 \mathrm{~cm}$, dan $R G K L: 2 \mathrm{~cm}$. Pada akhir pengukuran atau umur 8 minggu, tinggi tanaman rumput Gajah kerdil berturut turut RG: $51 \mathrm{~cm}, R G L: 53 \mathrm{~cm}, R G K: 61$ $\mathrm{cm}$ dan RGKL : $59 \mathrm{~cm}$. Hasil penelitian tersebut ternyata tidak berbeda dengan hasil penelitian Sirait et al. (2015) yang menanam rumput Gajah Kerdil di lahan dataran rendah Sumatera Utara, menunjukkan bahwa panjang daun rumput Gajah Kerdil pada umur 8 bulan berkisar $50-65 \mathrm{~cm}$. Hal ini memperlihatkan bahwa rumput Gajah Kerdil dapat tumbuh dan berkembang di lahan bekas penambangan batu kapur yang telah berumur lebih dari 10 tahun. Adapun pertumbuhan panjang daun rumput Gajah Kerdil pada berbagai metode penanaman dari umur 1 8 minggu dapat dilihat pada Gambar 4 . 


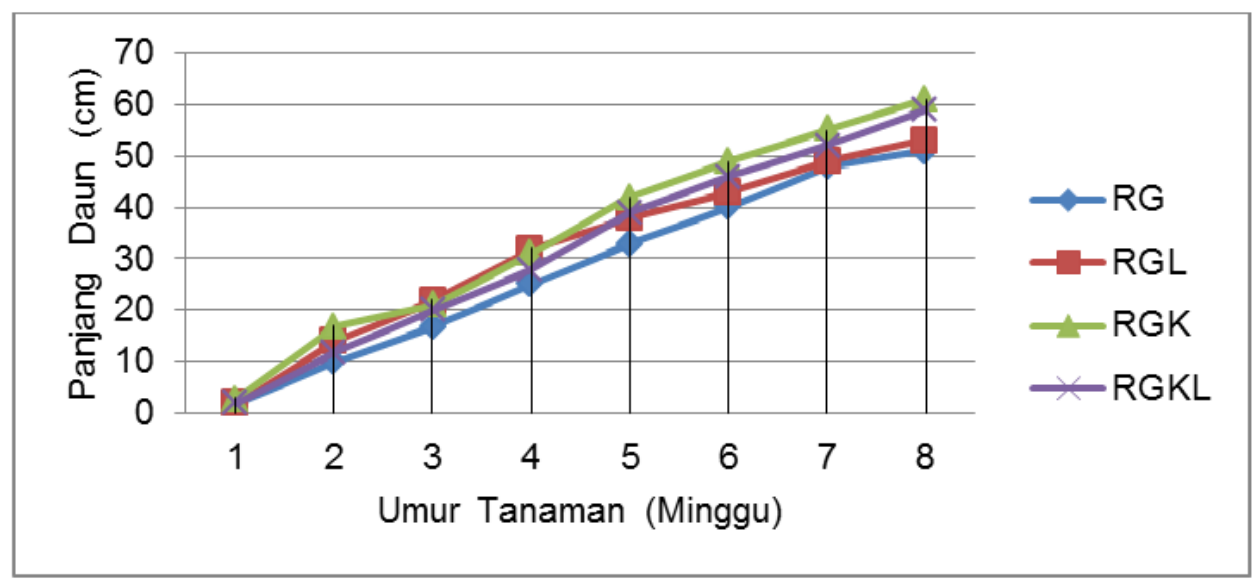

Gambar 4. Pertumbuhan panjang daun rumput Gajah Kerdil di lahan bekas penambangan batu kapur di kawasan karst Gombong

Hasil analisis ragam menunjukkan bahwa metode penanaman berpengaruh nyata $(P<0,05)$ terhadap panjang daun rumput Gajah Kerdil. Berdasarkan hasil uji lanjut memperlihatkan bahwa RG dan RGL mempunyai panjang daun yang sama namun berbeda dengan RGK dan RGKL, sedangkan RGK dan RGKL mempunyai panjang daun yang sama. Tingginya panjang daun rumput Gajah Kerdil pada RGK dan RGKL disebabkan karena pengaruh dari penambahan kompos kambing $1,5 \mathrm{~kg} / \mathrm{m}^{2}$. Penelitian Marrasing (2013) di lahan Fakultas Peternakan Unsrat, Manado menunjukkan bahwa pertumbuhan rumput Gajah Dwarf meningkat setelah dipupuk dengan pupuk organik hasil fermentasi EM4 mengandung Nitrogen tinggi yaitu 1,37\% dan Kalium tinggi sebesar 2,03\%. Hasil uji lanjut panjang daun rumput Gajah Kerdil di lahan bekas penambangan batu kapur pada berbagai metode penanaman dapat dilihat pada Gambar 5.

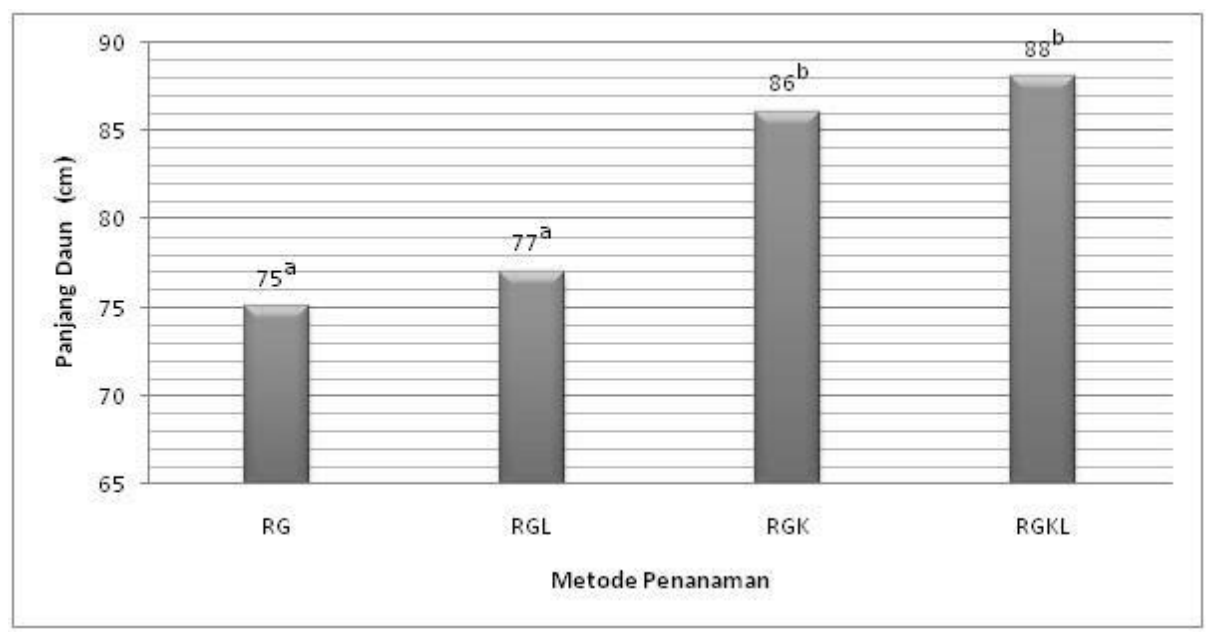

Gambar 5. Rataan panjang daun rumput Gajah Kerdil di lahan bekas penambangan batu kapur pada berbagai metode penanaman

Keterangan : ${ }^{a, b}$ huruf yang berbeda pada diagram menunjukkan perbedaan nyata $(P<0,05)$

\section{Lebar Daun}

Lebar daun rumput Gajah Kerdil awal pertumbuhan yaitu pada umur 1 minggu tidak dapat diukur karena kondisi daun belum tumbuh sempurna, namun pada umur 2 minggu lebar daun rumput Gajah Kerdil adalah $R G: 8 \mathrm{~mm}$, RGL : $6 \mathrm{~mm}$, RGK : $7 \mathrm{~mm}$ dan RGKL : $8 \mathrm{~mm}$.
Pada akhir pengukuran yaitu umur 8 minggu lebar daun rumput Gajah Kerdil berkisar $25-30 \mathrm{~mm}$ dengan rincian sebagai berikut : $R G: 27 \mathrm{~mm}$, RGL : $25 \mathrm{~mm}$, RGK : $28 \mathrm{~mm}$ dan RGKL : $30 \mathrm{~mm}$. Pertumbuhan lebar daun rumput Gajah Kerdil di lahan bekas penambangan batu kapur pada berbagai metode penanaman dapat dilihat pada Gambar 6. 


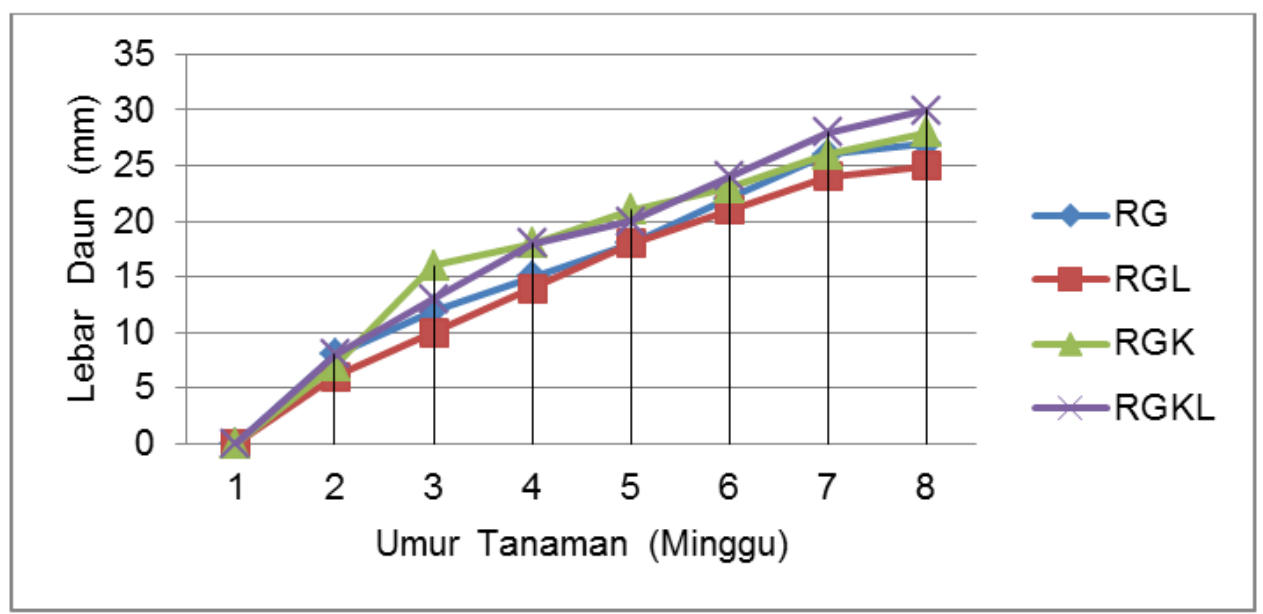

Gambar 6. Pertumbuhan lebar daun rumput Gajah Kerdil di lahan bekas penambangan batu kapur di kawasan karst Gombong.

Hasil analisis ragam menunjukkan bahwa metode penanaman berpengaruh tidak nyata $(P>0,05)$ terhadap lebar daun rumput Gajah Kerdil. Berdasarkan hasil analisis ragam memperlihatkan bahwa RG, RGL, RGK dan RGKL mempunyai lebar daun yang sama. Hasil analisis ragam menunjukkan bahwa lebar daun rumput Gajah Kerdil pada umur 8 minggu telah mencapai pertumbuhan yang maksimal.

\section{Daftar Referensi}

Nurshanti D.F.. 2009. Pengaruh Pemberian Pupuk Organik Terhadap Pertumbuhan dan Hasil Tanaman Sawi Caisim (Brassica Juncea L.). AgronobiS, Vol. 1, No. 1, Maret $2009: 89-98$.

Kozloski G.V, J. Perottoni, L.M.B Sanchez. 2005. Influence of regrowth age on the nutritive value of dwarf elephant grass hay (Pennisetum purpureum Schum. cv. Mott) consumed by lambs. Animal Feed Science and Technology. Vol.119, issues 1-2, 7 March 2005 : 1 - 11.

Marassing J.S., W.B. Kaunang, F. Dompas, dan N. Bawole. 2013. Produksi dan Kualitas Rumput Gajah Dwarf (Pennisetum purpureum cv. Mott) yang Diberi Pupuk Organik Hasil Fermentasi EM4. Jurnal Zootek Vol. 32,No. 5 : 158 - 171.

Menteri Energi Sumber Daya Mineral. 2014. Surat Keputusan Menteri Energi Sumber Daya Alam Republik Indonesia Nomor : 3043. K/40/MEM/2014 tanggal 4 Juli 2014 tentang Penetapan Kawasan Bentang Alam Kars Gombong.

\section{Simpulan}

Hasil penelitian dapat disimpulkan bahwa rumput Gajah Kerdil (Pennisetum purpureum 'Mott') mempunyai tingkat pertumbuhan yang cukup tinggi di lahan terbuka bekas penambangan batu kapur kawasan karst Gombong. Pertumbuhan rumput Gajah Kerdil (Pennisetum purpureum 'Mott') di lahan terbuka bekas penambangan batu kapur dipengaruhi oleh pemberian kompos kambing dan penanaman legum kacang tanah (Arachis hypogaea L.).

Menteri Energi Sumber Daya Mineral. 2003. Surat Keputusan Menteri Energi Sumber Daya Alam Republik Indonesia Nomor : 961.K/40/MEM/2003 tanggal 23 Juli 2003 tentang Penetapan Kawasan Kars Gombong Kabupaten Kebumen Jawa Tengah.

Menteri Energi Sumber Daya Mineral. 2000. Surat Keputusan Menteri Energi Sumber Daya Alam Republik Indonesia Nomor : 1456.K/20/MEM/2000 tanggal 3 Nopemberi 2000 tentang Pedoman Pengelolaan Kawasan Kars.

Purnaweni, H.. 2014. Kebijakan Pengelolaan Lingkungan di Kawasan Kendeng Utara Provinsi Jawa Tengah. Jurnal IImu Lingkungan. Vol. 12 issue $1: 53-65$

Rusdy, M. 2012. Produksi bahan kering, kompatibilitas biologis dan kualitas tanaman campuran rumput Benggala (Brachiaria decumbens) dan centro (Centrosema pubescens). Pastura Vol. 2 No. $1: 17-20$

Utama W., K. Wijaya, R. Aldi, H. Farida, Budi, dan Suto. 2016. Inventarisasi Potensi Kawasan 
Karst Pamekasan Madura Utara. Jurnal Geosaintek 02 / 03 : 201-212.

Sarwanto D., S.E. Tuswati, dan P. Widodo. 2015. Keragaman dan Produktivitas Hijauan Pakan Indigenous pada Berbagai Tingkat Kerapatan Vegetasi di Pegunungan Kapur Gombong Selatan. Biosfera 32 (3) September 2015 : 147 - 153.

Sarwanto, D dan C.H. Prayitno. 2015. The Diversity and Productivity of Indigenous Forage in Former Limestone Mining Quarry in Karst Mountain of Southern Gombong, Central Java Indonesia. Journal Animal Production. Vol. 17 No.2 (2015) May : $69-$ 75.

Sirait J., A. Tarigan, K. Simanihuruk. 2015. Karakteristik Morfologi Rumput Gajah Kerdil (Pennisetum purpureum cv. Mott) Pada Jarak Tanam yang Berbeda di Dua Agroekosistem di Sumatera Utara. Prosiding Seminar Nasional Teknologi Peternakan dan Veteriner : 641 - 649.

Steel, R.G.D dan J.H. Torrie, 1993. Prinsip dan Prosedur Statistika : Suatu pendekatan biometrik. Penerbit PT Gramedia Pustaka Utama, Jakarta.

Tudsri S., S.T. Jorgensen, P. Riddach and A. Pookpakdi. 2002. Effect of cutting height and dry season closing date on yield and quality of five napier grass cultivars in Thailand. Tropical Grasslands 36 : 248252.

Urribarri, L., A. Ferrer and A. Colina. 2005. Leaf Protein from Ammonia-Treated Dwarf Elephant Grass (Pennisetum purpureum Schum cv. Mott). Applied Biochemistry and Biotechnology 121- $124: 721$ - 730.

Wijitphan, S., P. Lorwilai and C. Arkaseang. 2009. Effects of plant spacing on yields and nutritive values of Napier Grass (Pennisetum purpureum Schum.) under intensive management of nitrogen fertilizer and irrigation. Pakistan Journal of Nutrition $8: 1240-1243$.

Zhang X., Hongru Gu, Chenglong Ding, Xiaoxian Zhong, Jianli Zhang and Nengxiang Xu. 2010. Path coefficient and cluster analyses of yield and morphological traits in Pennisetum purpureum. Tropical Grasslands 44 : 95-102

Zhou C., B.M. Svensson, Junhua Yan, Xun Chen, and Kun Li. 2014. Ecological Compensation: A key to sustainable development in the Guizhou Province karst region, Southwest China. Open Journal of Forestry. 4 : 212 - 222. 